\title{
Refractory Hypopharyngeal Squamous Cell Carcinoma
}

National Cancer Institute

\section{Source}

National Cancer Institute. Refractory Hypopharyngeal Squamous Cell Carcinoma. NCI

Thesaurus. Code C148382.

Hypopharyngeal squamous cell carcinoma that does not respond to treatment. 